\title{
MET NM_000245.3:C.3749T>C
}

National Cancer Institute

\section{Source}

National Cancer Institute. MET NM 000245.3:C.3749T>C. NCI Thesaurus. Code

C162276.

A nucleotide substitution at position 3749 of the coding sequence of the MET gene where thymine has been mutated to cytosine. 